Research Article

\title{
Synthesis and Biological Evaluation of Some 1,8-Naphthalimide-Acridinyl Hybrids
}

\author{
Rui Chen, ${ }^{1,2}$ Caiying Yuan, ${ }^{1}$ Yogini Jaiswal, ${ }^{3}$ Lini Huo $\mathbb{D}^{1},{ }^{1}$ Dianpeng Li $\mathbb{D},{ }^{2,4}$ \\ Leonard Williams $\mathbb{D}^{3},{ }^{3}$ Jing Zhong, ${ }^{1}$ and Yan Liang ${ }^{5}$ \\ ${ }^{1}$ Guangxi University of Chinese Medicine, Nanning 530222, China \\ ${ }^{2}$ School of Chemistry and Chemical Engineering, Guangxi University, Nanning 530004, China \\ ${ }^{3}$ Center for Excellence in Post-Harvest Technologies, North Carolina A\&T State University, \\ The North Carolina Research Campus, 500 Laureate Way, Kannapolis, NC 28081, USA \\ ${ }^{4}$ Guangxi Key Laboratory of Functional Phytochemicals Research and Utilization, Guangxi Institute of Botany, \\ Guangxi Zhuang Autonomous Region and Chinese Academy of Sciences, Guilin, Guangxi 541006, China \\ ${ }^{5}$ Guangxi Medical University, Nanning 530021, China
}

Correspondence should be addressed to Lini Huo; huolini@126.com and Dianpeng Li; ldp@gxib.cn

Received 20 January 2020; Revised 12 April 2020; Accepted 18 May 2020; Published 5 August 2020

Academic Editor: Maria P. Robalo

Copyright (c) 2020 Rui Chen et al. This is an open access article distributed under the Creative Commons Attribution License, which permits unrestricted use, distribution, and reproduction in any medium, provided the original work is properly cited.

In the present study, the synthesis of three 1,8-naphthalimide-acridinyl hybrids (2a, $\mathbf{2 b}$, and $\mathbf{5 b}$ ) using $\mathrm{N}$-amido-1,8-naphthalimides (1 and 4) and acridinyl isothiocyanates is reported. The newly synthesized hybrids were evaluated for their anticancer activity in six human cancer cell lines (HL-60, MT-4, HepG2, HeLa, SK-OV-3, and MCF-7). Their inhibition activity against DNA-topoisomerase I (Topo I) and Electrophorus electricus acetylcholinesterase (AChE) was also studied. The results indicate that $\mathbf{2 b}$ displayed good cytotoxicity for MT-4, HepG2, HeLa, and SK-OV-3 with the $\mathrm{IC}_{50}$ values of $14.66 \pm 0.31,27.32 \pm 2.67,17.51 \pm 0.34$, and $32.26 \pm 1.74 \mu \mathrm{M}$, respectively. All compounds, especially $\mathbf{2 b}$, exhibited obvious bands corresponding to DNA fragments at $0.5 \mathrm{mM}$ concentration, further confirming the pharmacological mechanism related to the Topo I inhibitory activities. In addition, compound 2a exhibited higher inhibition activity against $\mathrm{AChE}$ than $\mathbf{2 b}$ and $\mathbf{5 b}$, with $\mathrm{IC}_{50}$ values of $0.32 \pm 0.04 \mathrm{mM}$, and the acridinyl ring may contribute to the activity of $\mathbf{2 a}$.

\section{Introduction}

Treatment of cancer remains a challenge for the global population, researchers, and the medical field. Antitumor agents with DNA intercalative properties have been widely studied. They are characterized by the presence of a planar chromophore, a tri- or tetracyclic ring system, and one or two flexible substituent groups [1]. Typically, planar structure of DNA-intercalating agents can strongly bind to DNA, resulting in the death of cancer cells [2]. Acridine derivatives are extensively investigated as DNA intercalators because of their planar structure. Examples include nitracrine 1, m-AMSA 2, and DACA 3. Some of them are reported to be clinically useful as antitumor agents (Figure 1) [3-5]. Naphthalimides have been extensively investigated as anticancer agents. This is because they possess the desirable $\pi$-conjugated backbone with double amide moieties which can readily interact with various active targets. Significant examples include compounds such as amonafide 3, mitonafide 4, and DMP 840-bisnafide 5 (Figure 2) [6]. This encourages our strong interest in modifying acridine ring or naphthalimide, for identifying potential novel antitumor drugs $[7,8]$.

Topoisomerases have been indicated to be the necessary DNA targeting enzymes, that initially induce a cleavage of DNA strand, and follow by the reorganization and reconnection of the damaged DNA strand [9]. Therefore, most useful DNA-intercalating agents were also related to the inhibition of DNA-topoisomerase I or II [1, 10-12]. Some acridine derivatives [13-15] and 1,8-naphthalene imide derivatives [16] could exert their cytotoxicity through suppressing DNA or RNA synthesis, thus causing the 


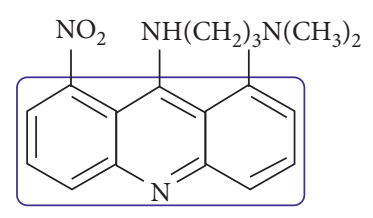

(a)

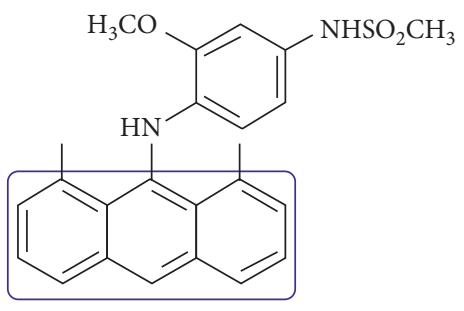

(b)

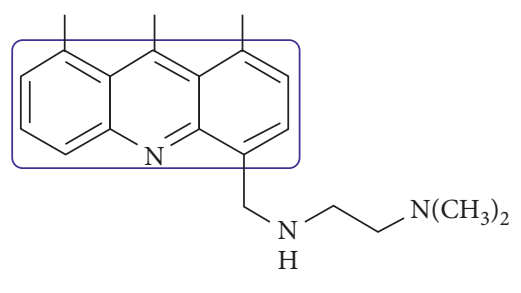

(c)

FIgURE 1: Structure of some acridine derivatives: (a) nitracrine 1, (b) m-AMSA 2, and (c) DACA 3.

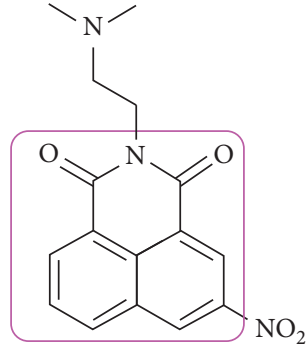

(a)

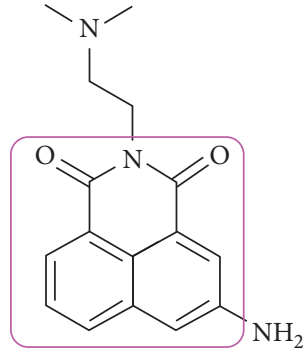

(b)

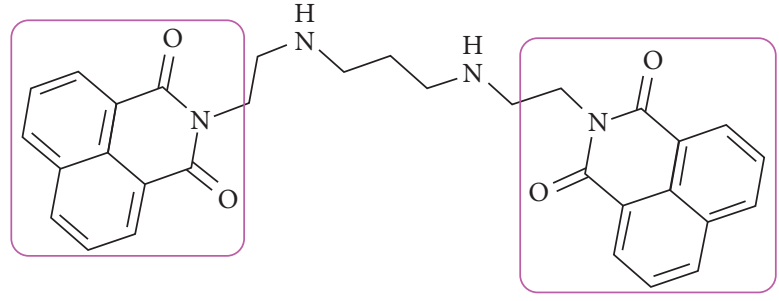

(c)

Figure 2: Structure of some naphthalimides: (a) amonafide 4, (b) mitonafide 5, and (c) DMP 840-bisnafide 6.

inhibition of DNA-topoisomerase I (Topo I) or topoisomerase II (Topo II). Reports indicate that the bis-derivatives which are constituted by two planar cores connected by one bridge possessed DNA binding capacity and were effective in killing cancerous cells [2]. In order to develop a new topoisomerase inhibitor, we developed new acridinenaphthalimide hybrids with thiocarbamide as the linkage (Figure 3). The anticancer and DNA-Topo I inhibitory activities of the synthesized derivatives were evaluated at the same time. Besides, tacrine is the best-known acetylcholinesterase (AChE) inhibitor, and its analogue acridine derivative also exhibits potent anti-AChE activity $[17,18]$. Thus, the anti-AChE activities of all compounds were also investigated in this study. The possible pharmacological mechanisms of all compounds with two targets (Topo I and AChE) were investigated by molecular docking, in order to identify lead Topo I or AChE inhibitors.

\section{Materials and Methods}

\subsection{Chemistry}

2.1.1. General. Acridine isothiocyanate derivatives were synthesized according to our previously published method [19]. Other reagents and solvents were of reagent grade and were obtained from Aladdin Chemical Reagent Limited Company (Shanghai, China). All yields mentioned refer to the yields of isolated products after purification. The intermediates and the synthesized products were fully characterized by spectroscopic data. The Bruker DRX-500 $\left({ }^{1} \mathrm{H}: 600 \mathrm{MHz}\right.$; ${ }^{13} \mathrm{C}: 150 \mathrm{MHz}$ ) equipment was used to record the NMR spectra, with DMSO- $d^{6}$ as the solvent. Chemical shifts $(d)$ were presented in the form of parts per million (ppm), while the $J$ values were presented in hertz $(\mathrm{Hz})$. Mass spectra were generated using a Thermo Fisher LCQ Fleet (ESI) machine. Agilent 1200 high-performance liquid chromatograph (HPLC) with DAD detector was used for chromatographic detection. XT-4A melting point apparatus was employed to measure the melting points, with no correction.

2.1.2. Synthesis of N-Amido-1,8-naphthalimide (1) and $\mathrm{N}$-Amido-4-bromine-1,8-naphthalimide (3). Compounds 1 and 3 were synthesized according to the procedure found in the literature $[20,21]$ after minor modifications.

About $0.99 \mathrm{~g}$ of anhydride naphthalene $(5 \mathrm{mmol})$ was dissolved in $50 \mathrm{~mL}$ DMF. Later, an excess of $85 \% \mathrm{w} / \mathrm{w}$ hydrazine hydrate $(10 \mathrm{~mL})$ was added, followed by refluxing for $4 \mathrm{~h}$. The mixture was then cooled, and the precipitated solids were filtered and recrystallized from ethanol to obtain a solid yellow compound (1).

About $2.5 \mathrm{~mL}$ of $85 \% \mathrm{w} / \mathrm{w}$ hydrazine hydrate was added dropwise into $25 \mathrm{~mL}$ suspension of $95 \%$ ethanol and $1.39 \mathrm{~g} 4$ bromo-1,8-naphthalic anhydride $(5 \mathrm{mmoL})$. After mechanical stirring for $5 \mathrm{~h}$ under ambient temperature, the precipitate was collected through filtration, rinsed with 95\% ethanol, and dried under vacuum. The resulting solid was then recrystallised with chlorobenzene to obtain the pure product (3).

Compound 1: orange powder, yield: $82 \%, \mathrm{~m}$. p.: $260-265^{\circ} \mathrm{C}\left(263-265^{\circ} \mathrm{C}\right.$ in [20]); compound 3: faint yellow powder, yield: $85 \%$, m. p.: $216-219^{\circ} \mathrm{C}\left(219-220^{\circ} \mathrm{C}\right.$ in [22]).

2.1.3. Synthesis of N-Amido-4-propyl-1,8-naphthalimide (4). According to the method reported in the literature [20], $15 \mathrm{~mL}$ ethylene glycol monomethyl ether containing $0.15 \mathrm{~g}$ 


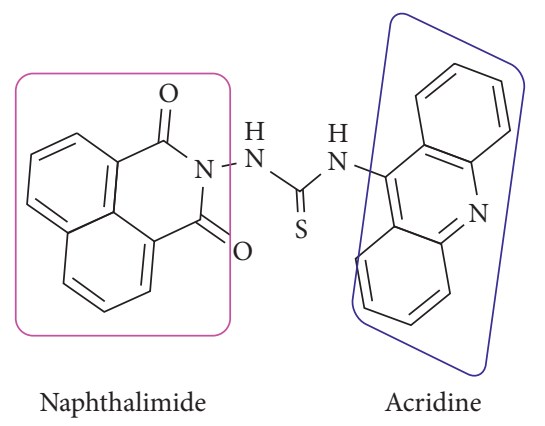

Figure 3: Design of acridine-naphthalimide hybrids.

(0.5 mmoL) of compound 3 and $1 \mathrm{~mL}$ propylamine $(0.72 \mathrm{mmol})$ was placed into a $50 \mathrm{~mL}$ round-bottom flask. The reaction mixture was then refluxed for $3.5 \mathrm{~h}$. After cooling to room temperature, $50 \mathrm{~mL}$ ice water was added, and the precipitate was collected by filtration, washed with water and dried under vacuum. The crude solid was recrystallized from chloroform to give yellow needles (4) with a yield of $65.43 \%$.

2.1.4. General Procedure for Synthesis of Acridinyl-1,8naphthalimide Hybrids (2) or (5). About $0.46 \mathrm{mmoL}$ of $\mathrm{N}$-amido-1,8-naphthalimide (1) or N-amido-4-propyl-1,8naphthalimide (4) was dissolved in $20 \mathrm{~mL}$ acetonitrile by heating to reflux, followed by the addition of 0.46 (for the synthesis of compound 2) or $0.92 \mathrm{mmoL}$ (for the synthesis of compound 5) acridine derivatives (a, b) into the resultant solution. The reaction mixture was then refluxed for $12-24 \mathrm{~h}$ at $80^{\circ} \mathrm{C}$, and the progress of the reaction was monitored by thin-layer chromatography (TLC). The resultant precipitate was filtered and washed with hot chloroform to obtain pure product (2) or (5).

1-(1,8-Naphthalimide)-3-(2-methoxyacridinyl) thiourea (2a), orange powder, yield: $56 \%$, m. p.: $220-222^{\circ} \mathrm{C}$; purity analysis: $91.12 \%$ by HPLC area normalization method (chromatographic column: CAPCELL PAK $\mathrm{C}_{18}$ $(4.6 \mathrm{~mm} \times 250 \mathrm{~mm}, 5 \mu \mathrm{m})$, mobile phase: methanol: water (80:20), detection wavelength: $210 \mathrm{~nm}$, flow rate: $1 \mathrm{~mL} / \mathrm{min}$, column temperature: $\left.30^{\circ} \mathrm{C}\right)$; ESI-MS $m / z: 477.45\left[(\mathrm{M}-\mathrm{H})^{-}\right]^{-1}$; ${ }^{1} \mathrm{H}$ NMR (DMSO- $\left.d^{6}, 600 \mathrm{MHz}\right) \delta 10.77$ (s, $\left.1 \mathrm{H},-\mathrm{NH}\right), 10.67$ (s, 1H, -NH), 8.68 (dd, $J=14.1,7.3 \mathrm{~Hz}, 2 \mathrm{H}, \mathrm{ArH}), 8.56-8.53$ $(\mathrm{m}, 2 \mathrm{H}, \operatorname{ArH}), 8.13(\mathrm{~d}, J=8.6 \mathrm{~Hz}, 1 \mathrm{H}, \operatorname{ArH}), 8.09$ (d, $J=9.4 \mathrm{~Hz}, 1 \mathrm{H}, \mathrm{ArH}), 8.02(\mathrm{~d}, J=8.5 \mathrm{~Hz}, 1 \mathrm{H}, \mathrm{ArH}), 7.95(\mathrm{t}$, $J=7.8 \mathrm{~Hz}, 2 \mathrm{H}, \mathrm{ArH}), 7.80-7.76(\mathrm{~m}, 1 \mathrm{H}, \mathrm{ArH}), 7.68$ (d, $J=7.7 \mathrm{~Hz}, 1 \mathrm{H}, \mathrm{ArH}), 7.55(\mathrm{dd}, J=9.3,2.7 \mathrm{~Hz}, 1 \mathrm{H}, \mathrm{ArH}), 7.47$ $(\mathrm{d}, J=7.5 \mathrm{~Hz}, 1 \mathrm{H}, \mathrm{ArH}), 4.12\left(\mathrm{~s}, 3 \mathrm{H},-\mathrm{OCH}_{3}\right) .{ }^{13} \mathrm{C} \mathrm{NMR}$ $\left(\mathrm{DMSO}-d^{6}, 150 \mathrm{MHz}\right) \delta 182.59,163.25,163.08,157.54$, $147.69,146.71,139.34,135.60,135.50,131.99,131.89,131.71$, $131.48,129.72,128.22,127.87,126.76,125.85,125.40,124.60$, $124.27,123.26,123.15,100.52,56.23$.

1-(1,8-Naphthalimide)-3-(benz[c]acridinyl) thiourea (2b): golden yellow powder, yield: $26 \%$, m. p.: $148-151^{\circ} \mathrm{C}$; purity analysis: $92.50 \%$ (the chromatographic conditions used were same as the ones used for 2a); ESI-MS $m / z: 497.46$ $\left[(\mathrm{M}-\mathrm{H})^{-}\right]^{-1},{ }^{1} \mathrm{H}$ NMR (DMSO- $\left.d^{6}, 600 \mathrm{MHz}\right) \delta 10.81(\mathrm{~s}, 2 \mathrm{H}$, -NH), 9.37 (dd, $J=5.9,3.2 \mathrm{~Hz}, 1 \mathrm{H}, \mathrm{ArH}), 8.72$ (d, $J=7.3 \mathrm{~Hz}$,
2H, ArH), 8.57 (d, $J=8.1 \mathrm{~Hz}, 2 \mathrm{H}, \mathrm{ArH}), 8.32(\mathrm{~d}, J=8.5 \mathrm{~Hz}$, $1 \mathrm{H}, \mathrm{ArH}), 8.18(\mathrm{~d}, J=8.4 \mathrm{~Hz}, 1 \mathrm{H}, \mathrm{ArH}), 8.05$ (dd, $J=5.8$, 3.1 Hz, 1H, ArH), 7.99-7.90 (m, 5H, ArH), 7.86-7.80 (m, 2H, ArH), 7.78-7.75 (m, 1H, ArH); ${ }^{13} \mathrm{C}$ NMR (DMSO- $d^{6}$, $150 \mathrm{MHz}) \delta 182.85,163.15,147.94,147.86,141.28,135.58$, $133.88,132.01,131.91,131.19,130.75,130.02,129.88,128.70$, $128.37,128.25,128.06,127.86,127.01,125.08,124.59,123.20$, 123.01, 122.13, 100.11, 79.72 .

1-(4-Propyl-1,8-naphthalimide)-3-(benz[c]acridinyl) thiourea (5b): orange-red powder, yield: $26.5 \%$; purity analysis: $94.66 \%$ (the chromatographic conditions used were same as the ones used for 2a); m. p.: 191-192 ${ }^{\circ} \mathrm{C}$; ESI-MS $m / z: 554.54$ [(M$\left.\mathrm{H})^{-}\right]^{-1},{ }^{1} \mathrm{H}$ NMR (DMSO- $\left.d^{6}, 600 \mathrm{MHz}\right) \delta 10.66$ (s, $\left.1 \mathrm{H},-\mathrm{NH}\right)$, 10.62 (s, 1H, -NH), 9.37 (dd, $J=5.9,3.2 \mathrm{~Hz}, 1 \mathrm{H},-\mathrm{NH}), 8.82$ (d, $J=8.4 \mathrm{~Hz}, 1 \mathrm{H}, \mathrm{ArH}), 8.63(\mathrm{~d}, J=7.3 \mathrm{~Hz}, 1 \mathrm{H}, \mathrm{ArH}), 8.45$ (d, $J=8.7 \mathrm{~Hz}, 1 \mathrm{H}, \operatorname{ArH}), 8.31(\mathrm{~d}, J=8.5 \mathrm{~Hz}, 1 \mathrm{H}, \operatorname{ArH}), 8.21$ (dd, $J=18.2,8.4 \mathrm{~Hz}, 1 \mathrm{H}, \mathrm{ArH}), 8.07-8.01(\mathrm{~m}, 1 \mathrm{H}, \mathrm{ArH}), 7.94$ (ddd, $J=19.1,12.0,4.6 \mathrm{~Hz}, 4 \mathrm{H}, \mathrm{ArH}), 7.85-7.79$ (m, 2H, ArH), 7.75 (dd, $J=11.0,4.8 \mathrm{~Hz}, 2 \mathrm{H}, \mathrm{ArH}), 6.87$ (d, $J=8.8 \mathrm{~Hz}, 1 \mathrm{H}, \mathrm{ArH}$ ), $3.38\left(\mathrm{dd}, J=12.7,6.9 \mathrm{~Hz}, 2 \mathrm{H},-\mathrm{CH}_{2}-\right), 1.79-1.67\left(\mathrm{~m}, 2 \mathrm{H},-\mathrm{CH}_{2}-\right.$ ), $0.98\left(\mathrm{t}, J=7.3 \mathrm{~Hz}, 3 \mathrm{H},-\mathrm{CH}_{3}\right) ;{ }^{13} \mathrm{C} \mathrm{NMR}$ (DMSO- $d^{6}$, $150 \mathrm{MHz}) \delta 182.82,163.60,162.43,151.67,147.94,147.84$, $141.68,135.39,133.90,131.71,131.21,130.68,130.52,129.97$, $129.79,129.66,128.67,127.99,126.86,125.07,124.88,124.79$, $123.22,123.13,123.08,122.40,120.80,108.24,104.44,45.05$, 21.59, 11.97.

\subsection{Biological Assays}

2.2.1. Cells and Control Compounds. Six types of human cancer cells (HL-60, MT-4, HepG2, HeLa, SK-OV-3, and MCF-7 cells), two types of human normal cells (BEAS-2B and LO2), and one type of neurocytoma SH-SY5Y cells were provided by Kunming Institute of Botany. These cells were cultured into the DMEM (Dulbecco's modified Eagle's medium; Sigma Chemical Co., St. Louis, MO) or RPMI-1640 (Roswell Park Memorial Institute medium; Sigma Chemical Co., St. Louis, MO) medium containing 10\% FBS (fetal bovine serum; GIBCO BRL Life Technologies. Inc., Grand Island, NY) with $5 \% \mathrm{CO}_{2}$ at $37^{\circ} \mathrm{C}$. RPMI-1640 medium was used only for suspension-cultured HL-60 cells. The test drugs were preserved at $5 \mathrm{mM}$ concentration in DMSO, and positive control (cisplatin, camptothecin, and doxorubicin) was preserved at $5 \mathrm{mM}$ concentration in sterile water at $-20^{\circ} \mathrm{C}$. The test solutions were freshly prepared for individual analysis, by diluting the stock solution with DMEM or RPMI-1640 to the final desired concentrations.

2.2.2. In Vitro Assay for Cytotoxicity. Cytotoxicity in cells was investigated by MTS method [23]. Briefly, cells $\left(4 * 10^{3}\right.$ cells/ well) were inoculated into the 96 -well plates at $37^{\circ} \mathrm{C}$ for $24 \mathrm{~h}$, followed by $48 \mathrm{~h}$ treatment with corresponding drugs or cisplatin. MTS (3-(4,5-dimethylthiazole-2-yl)-5-(3-carboxymethoxyphenyl)-2-(4-sulfophenyl)-2H-tetrazolium) (Promega, Madison, WI, USA) was added to the cells for $2-4 \mathrm{~h}$ to measure the number of live cells. Colorimetric measurements were taken at $492 \mathrm{~nm}$. The drug concentrations resulting in $50 \%$ inhibition of cell growth $\left(\mathrm{IC}_{50}\right)$ were determined. 
2.2.3. Topo I Inhibitory Activity. The catalytic activity of Topo I was determined in accordance with the literature reports, with supercoiled pBR32 DNA as the substrate [24]. Topo I and pBR322 were provided by Takara Bio Inc. One enzyme unit is referred to as the amount of enzyme that could totally relax $0.5 \mu$ g supercoiled pBR322 DNA at $37^{\circ} \mathrm{C}$ within $30 \mathrm{~min}$. Briefly, $20 \mu \mathrm{L}$ reaction mixture was added into the mixture containing $2 \mu \mathrm{L}$ of the $10 \mathrm{X}$ reaction buffer solution (supplemented with $500 \mathrm{mM}$ of KAc, $200 \mathrm{mM}$ of Tris-Ac, $100 \mathrm{mM}$ of $\left.\mathrm{Mg}(\mathrm{Ac})_{2}\right), 1 \mathrm{mg} / \mathrm{mL}$ of BSA, pBR322 DNA $(0.5 \mu \mathrm{g})$, and various compounds $(2 \mu \mathrm{L}, 0.5 \mathrm{mM})$. This was then diluted with distilled water to $19 \mu \mathrm{L}$. Later, one unit of Topo I (diluted to $1 \mathrm{unit} / \mu \mathrm{L}$ ) was added into the mixture and incubated for $30 \mathrm{~min}$ at $37^{\circ} \mathrm{C}$. The reaction was terminated by the addition of $0.5 \%$ SDS, bromophenol blue $(0.25 \mu \mathrm{g} / \mathrm{mL})$, and $15 \%$ glycerol. The reaction products were isolated after $50 \mathrm{~min}$ of horizontal $0.8 \%$ agarose gel electrophoresis in $1 \mathrm{X}$ Tris-acetate/EDTA buffer, at $80 \mathrm{~V}$ under ambient temperature. The gel was then stained using ethidium bromide $(5 \mu \mathrm{g} / \mathrm{mL})$, and the images were recorded by the Gel Documentation System (Bio-Rad, USA).

\subsubsection{Measurement of Acetylcholinesterase (AChE) Activity.} The activity of AChE was measured by the method proposed by Ellman et al. [25]. About $70 \mu \mathrm{L}$ of phosphate buffer $(0.1 \mathrm{M}$, $\mathrm{pH}$ 7.4) was added into $10 \mu \mathrm{L}$ organic solvent (control) or compound solution $(0.4 \mathrm{mM})$, followed by $45 \mathrm{~min}$ incubation period at $37^{\circ} \mathrm{C}$. About $10 \mu \mathrm{L}$ substrate thioacetylcholine (ATCI) $(1.25 \mathrm{mg} / \mathrm{mL})$ and $10 \mu \mathrm{L}$ Electrophorus electricus AChE $(1 \mathrm{U} / \mathrm{mL})$ were added in sequence, followed by sufficient mixing and $15 \mathrm{~min}$ incubation at $37^{\circ} \mathrm{C}$. Later, $50 \mu \mathrm{L}$ 5,5'-dithiobis(2-nitrobenzoic acid) (DTNB) $(2 \mathrm{mg} / \mathrm{mL})$ was added and left for $5 \mathrm{~min}$. Finally, the absorbance was measured at $412 \mathrm{~nm}$ and the inhibitory activity was calculated. The half-maximal inhibitory concentration $\left(\mathrm{IC}_{50}\right)$ values of the most sensitive compounds were measured with a series of concentrations $(0.1-1 \mathrm{mM})$.

2.3. Molecular Docking. Molecular docking between target proteins and ligands was performed using Surflex-Dock in Sybyl 2.0, which was according to our reported method in the literature [26]. This system is performed by generation of an idealized active site (Protocol) consisting of dummy atoms that guide the docking process. The crystal structures of both DNA-Topo I and AChE complex were downloaded based on RCSB website (http://www.rcsb.com) (PDB ID: 1T8I as well as 1UT6, respectively). The proteins were then imported into Surflex-Dock and prepared according to the following criteria using the biopolymer preparation tool: $\mathrm{H}$-Addition, H-Bond; removal of water molecules; termini treatment, charged; and protonation type of histidines.

The structures of the compounds were drawn using ChemDraw. Molecules in the training set were aligned by the FlexS in SYBYL. All values were assigned with valence, and the Gasteiger-Marsili charges were calculated for each compound. Ultimately, ligand docking under the SurflexDock GeomX precision was performed to dock the generated grid of protein and the ligands. The docking results were then imported into the LigPlot+ 2.1, and the combination between compounds and proteins was discussed regarding $\mathrm{H}$-Bond, conjugate action, and hydrophilic or hydrophobic action.

\section{Results and Discussion}

3.1. Synthesis. Three 1,8-naphthalimide-acridinyl hybrids $(\mathbf{2 a}, \mathbf{2 b}$, and $\mathbf{5 b}$ ) were synthesized according to the procedure shown in scheme 1 . The structures assigned to $\mathbf{2 a}, \mathbf{2} \mathbf{b}$, and $\mathbf{5 b}$ on the basis of MS, ${ }^{1} \mathrm{H}$ NMR, and ${ }^{13} \mathrm{C}$ NMR spectroscopic data are in accordance with the proposed molecular structures.

Intermediate $\mathrm{N}$-amido-1,8-naphthalimide (1 or $\mathbf{3}$ ) was prepared according to the method reported in the literature $[20,21]$. The target products of aroyl thiourea derivatives (2 or 5) were synthesized by nucleophilic addition reaction of $\mathrm{N}$-amido-1,8-naphthalimide derivatives (1 or $\mathbf{4}$ ), with isothiocyanate $\left(\mathbf{R}_{\mathbf{1}}=\mathbf{a}, \mathbf{b}\right)$. However, the molar ratio of them influences obviously the yield of the target product. Compounds $\mathbf{2 a}$ and $\mathbf{2 b}$ were synthesized successfully with intermediate $\mathbf{1}$ and isothiocyanate $\left(\mathbf{R}_{\mathbf{1}}=\mathbf{a}, \mathbf{b}\right)$ in a molar ratio of $1: 1$. Compound $\mathbf{5 b}$ was obtained by intermediate $\mathbf{4}$ and benz $[\mathbf{c}]$ acridine isothiocyanate $\left(\mathbf{R}_{\mathbf{1}}=\mathbf{b}\right)$ in a higher molar ratio of $1: 2$. The solvent $\mathrm{CH}_{3} \mathrm{CN}$ was found to be the most suitable solvent in this study based on the yield and purity obtained. However, the practical yields of $\mathbf{2} \mathbf{b}$ and $\mathbf{5 b}$ were still found to be less than $30 \%$, which may be related to steric hindrance of benz[c]acridine. The structures of compounds $\mathbf{2 a}, \mathbf{2 b}$, and $\mathbf{5 b}$ were confirmed by their ${ }^{1} \mathrm{H}$ NMR spectra, which displayed two characteristic NH signals of thiourea at a range of $\delta 10.62-11.47$. Their ${ }^{13} \mathrm{C}$ NMR spectra showed the characteristic carbon signals at a range of $\delta$ 182.85-162.43, attributed to two $\mathrm{C}=\mathrm{O}$ and one $\mathrm{C}=\mathrm{S}$. The ESI-MS indicated that the molecular weights were in accordance with the calculated value.

\subsection{Biological Activity}

3.2.1. Cytotoxicity Test. The in vitro cytotoxicities of the synthesized compounds were evaluated through the MTS assay. Six types of human cancer cells, two types of human normal cells, and one type of neurocytoma cells were used. These included HL-60 human leukemia, MT-4 human acute lymphoblast leukemia, HepG2 human hepatocarcinoma, HeLa human cervical cancer, SK-OV-3 human ovarian cancer, MCF-7 human breast carcinoma cells, human normal liver cells LO2, human normal lung epithelial cells BEAS-2B, and human neuroblastoma SH-SY5Y cells. The $\mathrm{IC}_{50}$ value was calculated according to the Reed and Muench method [27], with the consistence being used as the $X$-axis and the cell viability as the $Y$-axis. The assay results are shown in Table 1.

As shown in Table 1, 2b exhibited significant anticancer activity to most cell lines. The $\mathrm{IC}_{50}$ for MT-4, HepG2, HeLa, and SK-OV-3 cells were $14.66 \pm 0.31$, $27.32 \pm 2.67,17.51 \pm 0.34$, and $32.26 \pm 1.74 \mu \mathrm{M}$, respectively. But it was not better than the three positive controls in all cell lines. Both benz [c] acridine ring and naphthalene 


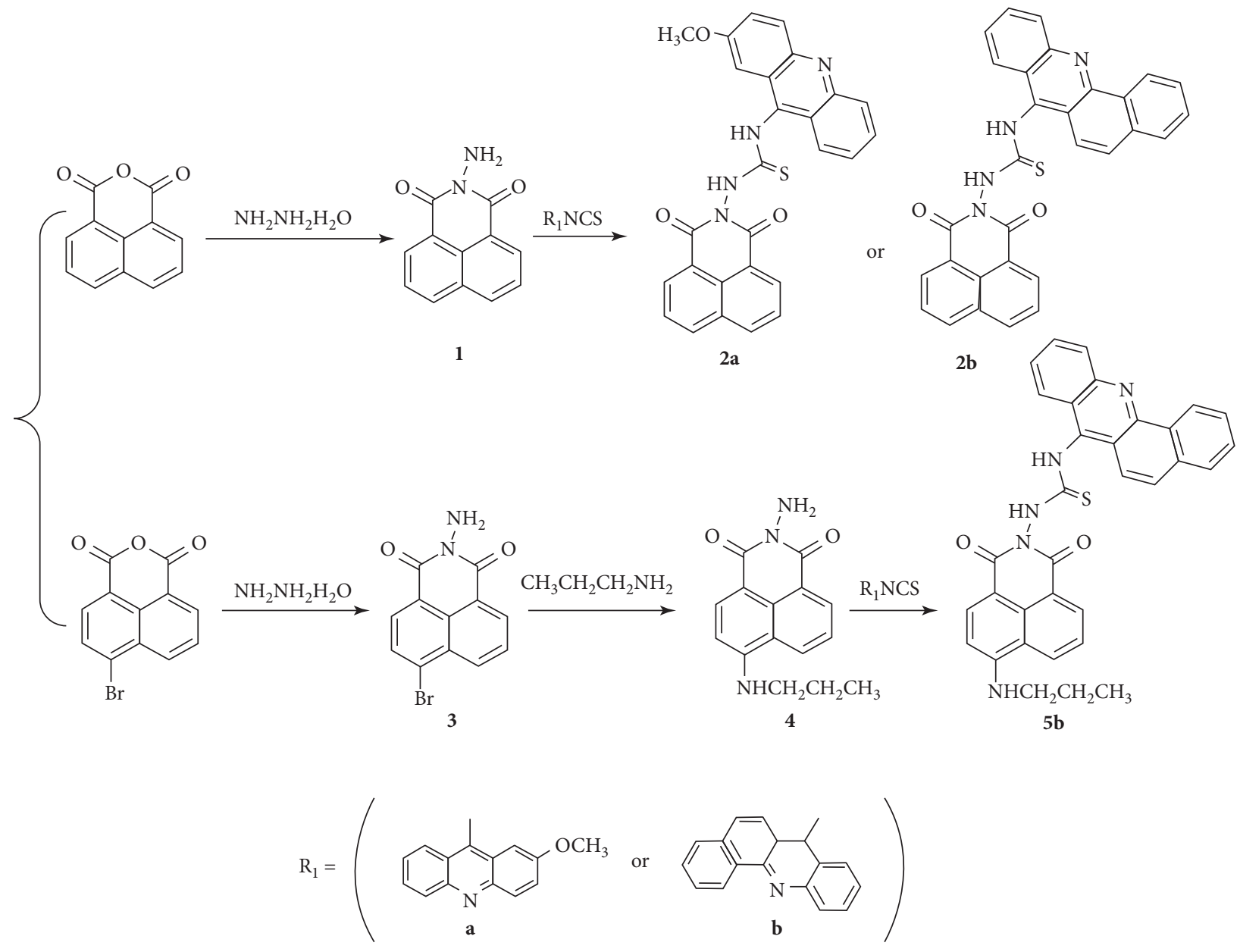

Scheme 1: The synthetic route of 1,8-naphthalimide-acridinyl hybrids.

TABle 1: The $\mathrm{IC}_{50}$ value of the synthesized compounds on different cell lines $(\mu \mathrm{M})$.

\begin{tabular}{lccccccccc}
\hline Compounds & HL-60 & MCF-7 & HepG2 & HeLa & SK-OV-3 & MT-4 & LO2 & BEAS-2B & SH-SY5Y \\
\hline 2a & $67.03 \pm 0.97$ & $78.63 \pm 1.78$ & $>100$ & $58.67 \pm 1.06$ & $88.74 \pm 2.43$ & $46.79 \pm 1.96$ & $>100$ & $>100$ & $>100$ \\
2b & $>100$ & $75.45 \pm 3.22$ & $27.32 \pm 2.67$ & $17.51 \pm 0.34$ & $32.26 \pm 1.74$ & $14.66 \pm 0.31$ & $>100$ & $>100$ & $22.34 \pm 0.98$ \\
5b & $>100$ & $>100$ & $>100$ & $>100$ & $>100$ & $>100$ & $>100$ & $>100$ & $57.72 \pm 2.14$ \\
Cisplatin & $3.70 \pm 0.14$ & $11.32 \pm 0.79$ & $5.83 \pm 0.14$ & $10.59 \pm 1.40$ & $16.02 \pm 0.30$ & $0.84 \pm 0.01$ & $10.49 \pm 0.38$ & $57.66 \pm 3.10$ & $24.08 \pm 1.23$ \\
Camptothecin & $12.25 \pm 1.06$ & $2.47 \pm 0.29$ & $1.32 \pm 0.62$ & $10.25 \pm 1.08$ & $8.22 \pm 0.66$ & $0.55 \pm 0.01$ & $0.030 \pm 0.002$ & $2.15 \pm 0.17$ & $12.11 \pm 0.43$ \\
Doxorubicin & $4.15 \pm 0.35$ & $2.13 \pm 0.02$ & $3.61 \pm 0.21$ & $12.53 \pm 1.22$ & $10.45 \pm 0.94$ & $0.78 \pm 0.02$ & $0.027 \pm 0.001$ & $5.16 \pm 0.55$ & $30.57 \pm 0.98$ \\
\hline
\end{tabular}

anhydride structure may have contributed to its anticancer activity of $\mathbf{2 b}$. However, $\mathbf{5 b}$ had no obvious toxic effect on any cancer cell lines, which may be related to the increase of the steric hindrance from the structure. It should be noted that all target compounds have no damage to normal cells LO2 and BEAS-2B with $\mathrm{IC}_{50}>100 \mu \mathrm{M}$, and they were less toxic than positive control. Compound $\mathbf{2} \mathbf{b}$ can thus be suggested as a potential candidate for development into antitumor drugs with high efficiency and low toxicity. In the meantime, the proliferation of human neuroblastoma SH-SY5Y cells was used to determine the neurotoxicity of all target compounds. The results indicated that compound $\mathbf{2 a}$ has no significant influence on the growth of SH-SY5Y cells with $\mathrm{IC}_{50}>100 \mu \mathrm{M}$. However, $\mathbf{2 b}$ and $\mathbf{2 c}$ have certain neurotoxicity with the $\mathrm{IC}_{50}$ value of $22.34 \pm 0.98$ and $57.72 \pm 2.14 \mu \mathrm{M}$, respectively.
3.2.2. Topo I Inhibitory Activity of Compounds. Literature indicates that stabilization of Topo I by topoisomerase poison is detrimental to cells. This is due to the disruption of DNA uncoiling, increased strand breaks, and unstable RNA transcripts, as well as incomplete DNA replication [28]. Topo I inhibitors such as camptothecin (CPT) have long been used for clinical cancer treatment. However, a lot of side effects of CPT have been reported, and it has been replaced by more effective and safer Topo I inhibitors [29]. To explore new inhibitors and their underlying mechanisms, Topo I inhibitory activity of all synthesized compounds was tested using the Topo I-mediated DNA cleavage assay [30]. Typically, the anti-Topo I potency of the compound would be associated with the number as well as intensity of gel bands related to the DNA fragments. As shown in Figure 4, all compounds could suppress the transformation 


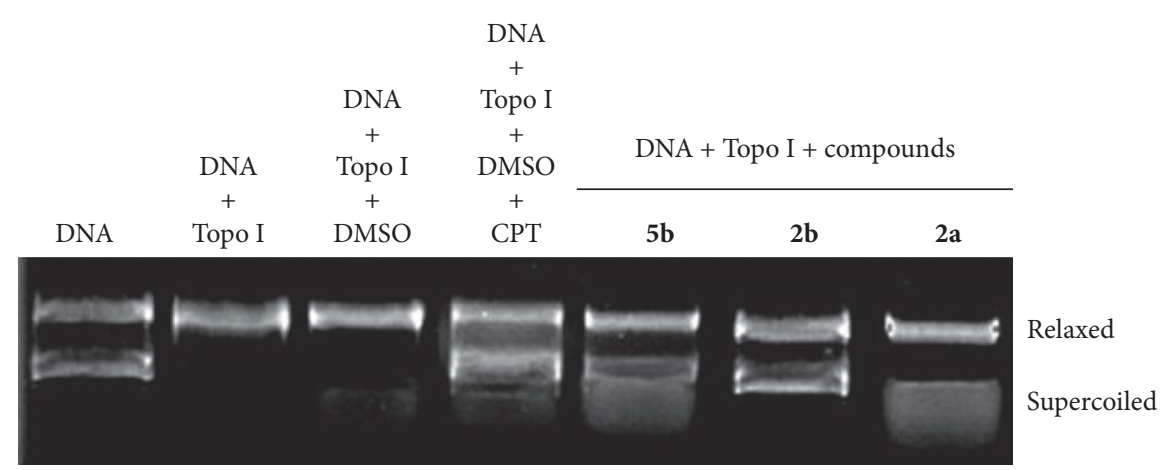

FIgURE 4: DNA-Topo I inhibitory activity of compounds $\mathbf{2 a}, \mathbf{2 b}$, and $\mathbf{5 b}$ at $0.5 \mathrm{mM}$ concentration using CPT as a positive control.

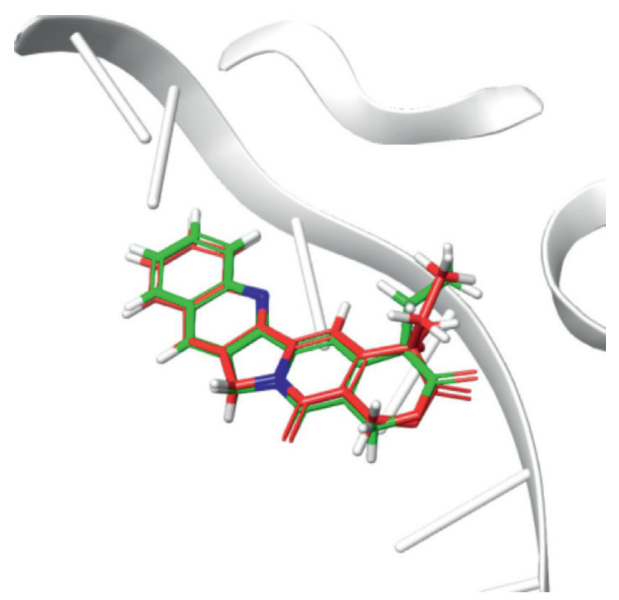

Figure 5: Result of validation for Topo I inhibitor (CPT), inside the enzyme active site (derived from PDB ID: 1T8I). Crystallographic inhibitors (red) and the top-ranked docking pose (green) from the Sybyl software are shown.

of the supercoiled DNA strand to the relaxed state. The compound $\mathbf{2 b}$ was found to be a promising Topo I inhibitor, whose activity was similar to that of CPT at the concentration of $0.5 \mathrm{mM}$. However, compounds $\mathbf{2 a}$ and $\mathbf{5 b}$ only displayed medium Topo I inhibitory activities. No obvious intensities of the bands corresponding to DNA below $0.5 \mathrm{mM}$ of all compounds were observed. The enzyme activities of compounds nearly confirmed to the MTS results. These results indicate that the anticancer mechanism of these compounds might be related to Topo I inhibitory.

3.2.3. Molecular Docking with Topo I. Molecular docking was carried out using Surflex-Dock in Sybyl 2.0, to investigate the pattern by which potent inhibitor binds with the human DNA-Topo I complex. The 1T8I (PDB code) structure in Protein Data Bank was improved and used in this study. To validate the molecular docking approach employed in this study, the crystallographic pose of CTP obtained from the structure of the DNA-Topo I complex (PDB ID: 1T8I) was compared with the top docking pose acquired in this study. Figure 5 depicts the superposition of the two binding poses of CTP, which are located within the DNA-Topo I binding site. Such superposition would result in a root-mean-square deviation (RMSD) of superposition of $0.54 \AA$. The obtained RMSD value was far lower than the well-established tolerance level of $2.0 \AA$ [31, 32], thus validating the adopted docking methodology.

Further, the interactions of $\mathbf{2} \mathbf{a}, \mathbf{2} \mathbf{b}$, and $\mathbf{5 b}$, with Topo I at the active site were analyzed and compared. The obtained results are indicated in Table 2 and Figure 6. Of them, the ligand-receptor complex that had the greatest total score was regarded as the most stable binding conformation. These conformations were then chosen to further explore the underlying binding mechanisms relying on hydrogen bond, hydrophobic interaction, and $\pi-\pi$ stacking [33]. As shown in Table 2, all tested compounds exhibited good inhibitory activities with the total score ranging between 8.98 and 9.53 , which were close to that of CPT (10.27). It was evident that $\mathbf{2 a}, \mathbf{2} \mathbf{b}$, and $\mathbf{5} \mathbf{b}$ could interact with various hydrophobic residues of Topo I, among which TGP11 and DC112 were common. The binding of $\mathbf{2} \mathbf{a}, \mathbf{2} \mathbf{b}$, and $\mathbf{5} \mathbf{b}$ with Topo I was found to involve the H-bonds with residues like ARG364, LYS425, GLU356, DT10, and DA113. In addition, the planar conjugated parts of $\mathbf{2 a}, \mathbf{2} \mathbf{b}$, and $\mathbf{5 b}$ were also effective for the same amino acid residue TGP 11 by the $\pi-\pi$ stacking force. All these interactions would assist these compounds in anchoring within the protein binding site. As predicted in this study, $\mathbf{2 a}, \mathbf{2 b}$, and $\mathbf{5 b}$ had exhibited similar Topo I 
TABLE 2: Interactions between DNA-Topo I (from PDB ID: 1T8I) and the synthesized compounds.

\begin{tabular}{|c|c|c|c|c|c|}
\hline Compound & Amino acid & Type & Distance $(\AA)$ & Hydrophobic residue & $\begin{array}{c}\text { Binding affinity } \\
\text { (Sybyl total score) }\end{array}$ \\
\hline \multirow{4}{*}{$2 a$} & TGP11 & $\pi-\pi$ & 3.6 & \multirow{4}{*}{$\begin{array}{l}\text { LYS374, GLU418, LYS425, GLU356, DC112, } \\
\text { ASN352, TGP11, DA113 }\end{array}$} & \multirow{4}{*}{9.53} \\
\hline & DA113 & $\pi-\pi$ & 3.79 & & \\
\hline & DA113 & $\pi-\pi$ & 3.78 & & \\
\hline & ARG364 & Hydrogen bond & 2.81 & & \\
\hline \multirow{5}{*}{$2 b$} & TGP11 & $\pi-\pi$ & 3.84 & \multirow{5}{*}{$\begin{array}{l}\text { GLU418, CD112, ASN352, ALA351, DA113, TGP11, } \\
\text { LYS374 }\end{array}$} & \multirow{5}{*}{8.98} \\
\hline & DA113 & $\pi-\pi$ & 4.06 & & \\
\hline & LYS425 & $\pi-\pi$ & 3.83 & & \\
\hline & LYS425 & Hydrogen bond & 3.28 & & \\
\hline & GLU356 & Hydrogen bond & 3.26 & & \\
\hline \multirow{5}{*}{$5 \mathbf{b}$} & TGP11 & $\pi-\pi$ & 3.46 & \multirow{5}{*}{ ASP533, ARG364, TGP11, TRP416, ASN352, ALA351 } & \multirow{5}{*}{9.40} \\
\hline & TGP11 & $\pi-\pi$ & 3.52 & & \\
\hline & DT10 & $\pi-\pi$ & 3.82 & & \\
\hline & DT10 & Hydrogen bond & 2.73 & & \\
\hline & DA113 & Hydrogen bond & 2.93 & & \\
\hline \multirow{8}{*}{ CPT } & TGP11 & $\pi-\pi$ & 3.68 & \multirow{8}{*}{ DC112, DA113, TGP11, DT10, DG12 } & \multirow{8}{*}{10.27} \\
\hline & TGP11 & $\pi-\pi$ & 3.91 & & \\
\hline & TGP11 & $\pi-\pi$ & 3.51 & & \\
\hline & DC112 & $\pi-\pi$ & 3.50 & & \\
\hline & DA113 & $\pi-\pi$ & 3.56 & & \\
\hline & DA113 & $\pi-\pi$ & 3.72 & & \\
\hline & ASP533 & Hydrogen bond & 3.24 & & \\
\hline & ARP364 & Hydrogen bond & 2.97 & & \\
\hline
\end{tabular}

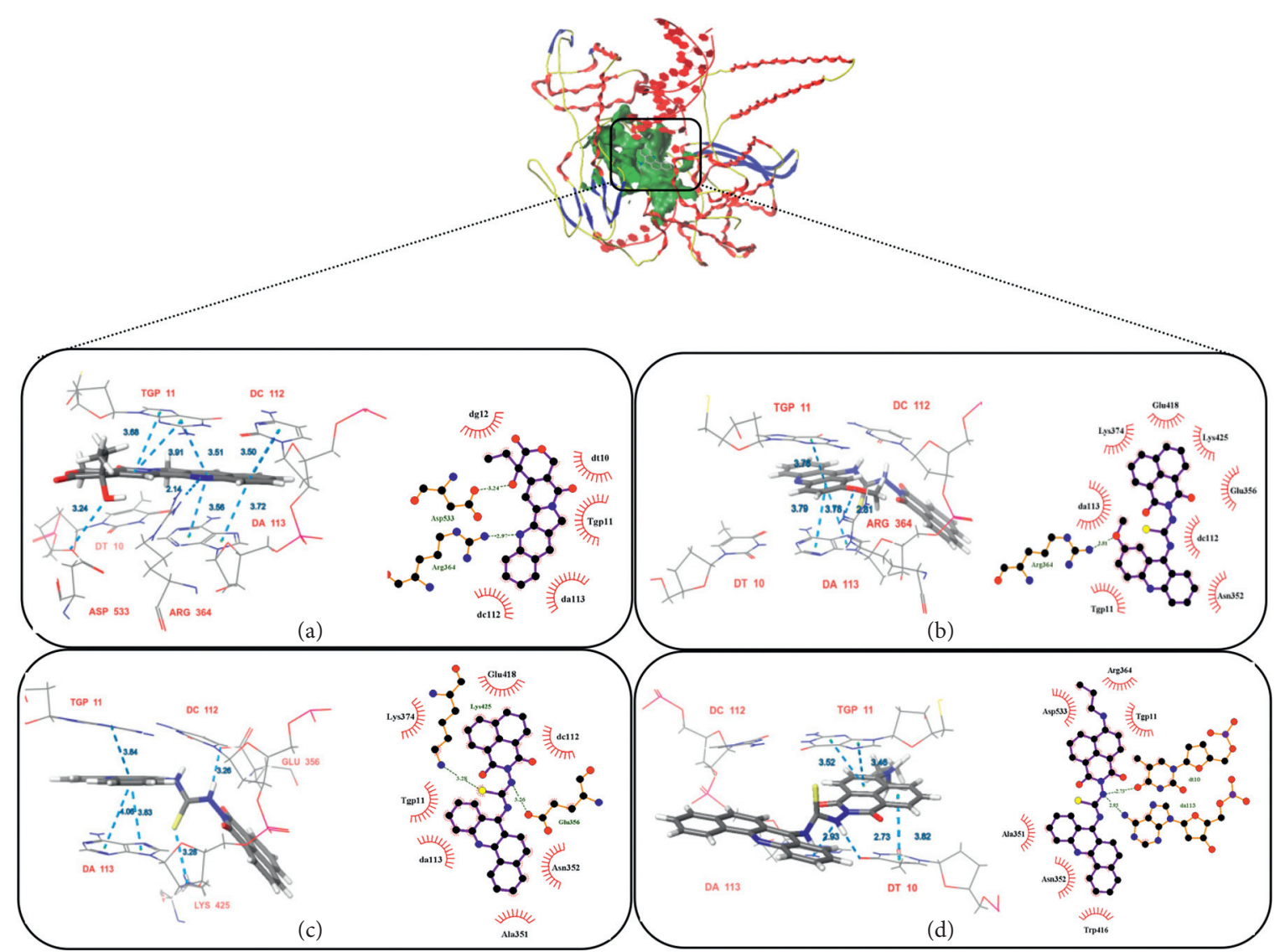

FIGURE 6: The best pose of the binding mode of compounds ((a): CPT, (b) 2a, (c) 2b, and (d) 5b) with DNA-Topo I complex (PDB ID: 1T8I). 


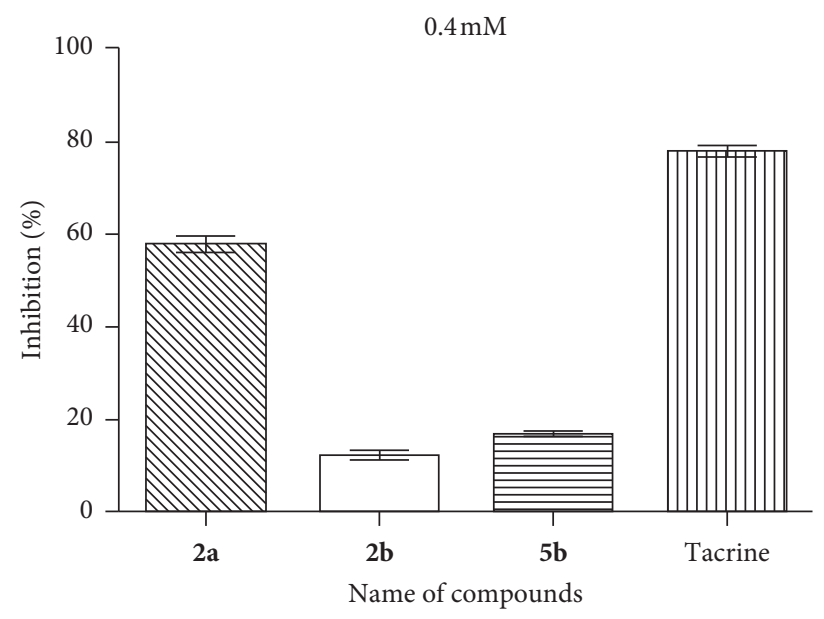

Figure 7: Anti-AChE activity of $\mathbf{2 a}, \mathbf{2 b}, \mathbf{5 b}$, and tacrine.

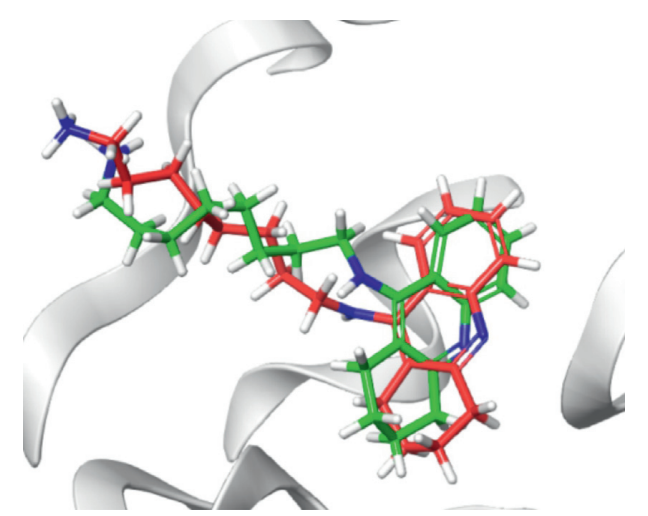

FIGURE 8: Result of validation for AChE inhibitor, tacrine derivative, inside the enzyme active site (derived from PDB ID 1UT6). Crystallographic inhibitors (red) and the top-ranked docking pose (green) from the Sybyl software are shown.

TABLE 3: Interactions between AChE (from PDB ID: 1UT6) and the compounds.

\begin{tabular}{|c|c|c|c|c|c|}
\hline Compound & Amino acid & Type & Distance $(\AA)$ & Hydrophobic residue & $\begin{array}{l}\text { Binding } \\
\text { affinity } \\
\text { (Sybyl total } \\
\text { score) }\end{array}$ \\
\hline \multirow{3}{*}{$2 a$} & TRP84 & $\pi-\pi$ & 3.55 & \multirow{3}{*}{$\begin{array}{l}\text { TUR70, TYR334, PHE330, TRP432, TYR442, TRP84, } \\
\text { GLY118, GLY117, ASP72, TYR121, TRP279 }\end{array}$} & \multirow{3}{*}{5.41} \\
\hline & TRP84 & $\pi-\pi$ & 3.39 & & \\
\hline & TRP84 & $\pi-\pi$ & 3.44 & & \\
\hline \multirow{5}{*}{$2 b$} & TRP84 & $\pi-\pi$ & 3.65 & \multirow{5}{*}{$\begin{array}{l}\text { GLY335, ILE286, TYR334, ASP72, PHE330, TRP432, } \\
\text { TRP84, GLY117, GLY118, TYR70 }\end{array}$} & \multirow{5}{*}{7.49} \\
\hline & TRP84 & $\pi-\pi$ & 2.96 & & \\
\hline & PHE330 & $\pi-\pi$ & 3.58 & & \\
\hline & TYR121 & Hydrogen bond & 3.12 & & \\
\hline & TYR121 & Hydrogen bond & 2.86 & & \\
\hline \multirow{7}{*}{$5 \mathbf{b}$} & TYR121 & Hydrogen bond & 2.72 & \multirow{7}{*}{$\begin{array}{l}\text { TRP279, TYR70, TYR334, ASP72, TRP84, GLU199, } \\
\text { TYR442, ILE439, PHE330, TRP432, TRP279 }\end{array}$} & \multirow{7}{*}{8.42} \\
\hline & PHE330 & $\pi-\pi$ & 3.97 & & \\
\hline & PHE330 & $\pi-\pi$ & 3.72 & & \\
\hline & TRP84 & $\pi-\pi$ & 3.46 & & \\
\hline & TRP84 & $\pi-\pi$ & 3.43 & & \\
\hline & TRP84 & $\pi-\pi$ & 3.97 & & \\
\hline & TRP84 & $\pi-\pi$ & 3.42 & & \\
\hline \multirow{4}{*}{ Tacrine derivative } & TRP279 & $\pi-\pi$ & 3.04 & \multirow{4}{*}{ TRP279, PHE290, TYR334, TRP84, PHE330, TYR70 } & \multirow{4}{*}{10.32} \\
\hline & TRP279 & $\pi-\pi$ & 3.51 & & \\
\hline & ASP72 & Hydrogen bond & 2.75 & & \\
\hline & SER81 & Hydrogen bond & 2.81 & & \\
\hline
\end{tabular}




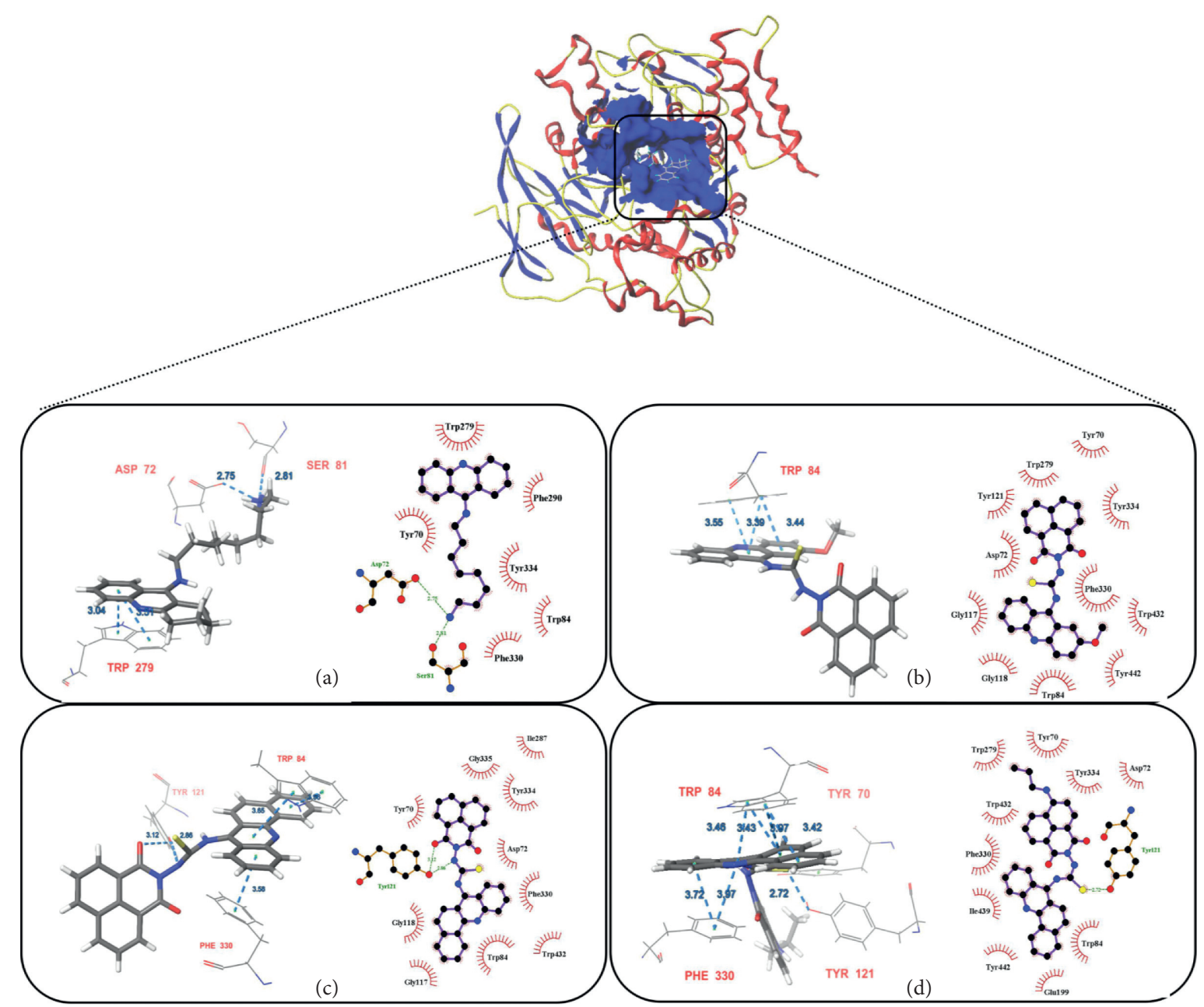

FIgURE 9: The best pose of the binding mode of compounds ((a) tacrine derivative, (b) 2a, (c) $\mathbf{2} \mathbf{b}$, and (d) 5b) with AChE complex (PDB ID: 1UT6).

inhibition activities as CPT, but the order of activity was not exactly the same as the docking study. There might be related to other pharmacological mechanisms.

3.2.4. Anti-AChE Activity. In the past decades, evaluation of the level of acetylcholine (Ach) based on cholinergic hypothesis has remained the main strategy for the drug design for the treatment of Alzheimer's disease (AD) [34]. In fact, most of the currently prescribed $\mathrm{AD}$ drugs are acetylcholinesterase inhibitors (AChEI), such as tacrine and rivastigmine [35]. Tacrine is a well-known tetrahydroacridine, which exhibits potent anti-AChE activity and is recognized to be clinically useful. The acridine groups of the synthesized compounds (2a, $\mathbf{2 b}$, and $\mathbf{5 b}$ ) share a similar structure with tacrine. Thus, the anti-AChE activity and related molecular docking studies were performed in this study. Their inhibitory effects on AChE at $0.4 \mathrm{mM}$ were evaluated according to the procedure described in the experimental section. As shown in Figure 7, only 2a $(58.65 \%)$ had exhibited significant inhibitory effect, compared to tacrine $(78.82 \%)$, with the $\mathrm{IC}_{50}$ values of $0.32 \pm 0.04$, and $0.06 \pm 0.01 \mathrm{mM}$, respectively. But $\mathbf{2 b}(12.10 \%)$ and $\mathbf{5 b}$
(16.06\%) had weak inhibitory effects on AChE. This may be due to the inability of the conjugated plane of benz[c]acridine ring, in insertion into the hydrophobic pocket of AChE.

3.2.5. Molecular Docking with Acetylcholinesterase (AChE). To understand the binding interactions between molecules and $\mathrm{AChE}$, molecular docking was carried out, and $\mathrm{AChE}$ (PDB code: 1UT6) was chosen for this study. According to the validation method described in Section 2.2.3, the docked ligands were discovered to have similar binding poses, to those of the co-crystallized ligand, with the RMSD of superposition of $1.53 \AA$ (Figure 8). These results validate the adopted docking methodology. Interactions between AChE and the selected compounds are presented in Table 3 and Figure 9 . We found that the docking results were not exactly consistent with the AChE activities in the experiment. The total scores of $\mathbf{2 b}$ and $\mathbf{5 b}$ were found to be 7.49 and 9.40 , respectively. However, both of them exhibited the lowest AChE inhibitory activity, which might be related to the low water solubility on account of the large rigid structure of the compound. In addition, compound $\mathbf{2 a}$ had the lowest total 
score of 5.41, but it exhibited better inhibitory activity than other compounds. As observed in the docking study, compound 2a was located at the hydrophobic pocket and was surrounded by the residues TUR70, TYR334, PHE330, TRP432, TYR442, TRP84, GLY118, GLY117, ASP72, TYR121, and TRP279. In addition, the 1,8-naphthalimide structure also formed the $\pi-\pi$ stacking with TYR84 (bond lengths of 3.54, 3.38, and 3.98).

\section{Conclusions}

In summary, in the current research work, three 1,8naphthalimide-acridinyl thiourea hybrids were synthesized. Among all these compounds, $\mathbf{2 a}$ and $\mathbf{2 b}$ exhibited relatively good anticancer activity against six human cancer cell lines, especially MT-4 cell lines. Besides, compound $\mathbf{2 b}$ can be considered as a possible Topo I inhibitor, exhibiting the best anticancer activity. Compound 2a displayed much better AChE inhibitory activity than the other two compounds. Thus, we infer that $\mathbf{2 a}$ and $\mathbf{2 b}$ can be selected as the representative compounds for further investigation as potential Topo I or anti-AChE inhibitors.

\section{Data Availability}

The data used to support the findings of this study are included within the article.

\section{Conflicts of Interest}

The authors declare no conflicts of interest in association with this manuscript.

\section{Acknowledgments}

This work acknowledges the support of the National Natural Science Foundation of China (No. NSFC21562009); Guangxi Natural Science Foundation (Nos. 2017GXNSFAA198171 and 2018GXNSFAA281189); Guangxi Key Laboratory of Zhuang and Yao Ethnic Medicine ((2013) No. 20); Collaborative Innovation Center of Zhuang and Yao Ethnic Medicine ((2014) No. 32); Guangxi Key Discipline Zhuang Pharmacology ((2013) No. 16); First-Class Discipline in Guangxi of Traditional Chinese Pharmacology (Direction of Ethnic Medicine) ((2018) No. 12); the Eighth Batch of Special Expert Projects of Guangxi Zhuang Autonomous Region (Study on the Quality Standard of Zhuang Ethnic Medicine ((2019) No. 13))); State Key Laboratory Cultivation Base for the Chemistry and Molecular Engineering of Medicinal Resources, Ministry of Science and Technology of China (CMEMR2015-B04 and CMEMR2015-B05); Promotion Project of Basic Ability of Young and Middle-Aged Teachers in Colleges and Universities in Guangxi (No. 2017KY0283); Project of Cultivating High-level Talent Teams in the Qi Huang Project of Guangxi University of Chinese Medicine (2018002); Hundred Talents Plan for the Introduction of High-Level Overseas Talents by Guangxi Colleges and Universities; and Program for Innovative
Research Team of High Education and Outstanding Scholar in Guang Xi [2019-52].

\section{Supplementary Materials}

${ }^{1} \mathrm{H}$ NMR, ${ }^{13} \mathrm{C}$ NMR, and MS spectrum of compounds $\mathbf{2 a}, \mathbf{2} \mathbf{b}$, and $\mathbf{5 b}$ are included in the supplementary materials. (Supplementary Materials)

\section{References}

[1] I. Sánchez, R. Reches, D. H. Caignard, P. Renard, and M. D. Pujol, "Synthesis and biological evaluation of modified acridines: the effect of $N$ - and $O$ - substituent in the nitrogenated ring on antitumor activity," European Journal of Medicinal Chemistry, vol. 41, no. 3, pp. 340-352, 2006.

[2] W. Shan-Shue, L. Yi-Jen, H. Shih-Chung et al., "Linkermodified triamine-linked acridine dimers: synthesis and cytotoxicity properties in vitro and in vivo," Bioorganic \& Medicinal Chemistry, vol. 15, no. 2, pp. 735-748, 2007.

[3] H. H. Lee, W. R. Wilson, D. M. Ferry, P. van Zijl, S. M. Pullen, and W. A. Denny, "Hypoxia-selective antitumor agents. 13. effects of acridine substitution on the hypoxia-selective cytotoxicity and metabolic reduction of the bis-bioreductive agent NitracrineN-oxide," Journal of Medicinal Chemistry, vol. 39, no. 13, pp. 2508-2517, 1996.

[4] B. F. Cain, G. J. Atwell, and W. A. Denny, "Potential antitumor agents. 17. 9-Anilino-10-methylacridinium salts," Journal of Medicinal Chemistry, vol. 19, no. 6, pp. 772-777, 1976.

[5] L. W. Deady, J. Desneves, A. J. Kaye et al., "Ring-substituted 11-oxo-11 H-indeno [1,2- b] quinoline-6-carboxamides with similar patterns of cytotoxicity to the dual topo I/II inhibitor DACA," Bioorganic \& Medicinal Chemistry, vol. 7, no. 12, pp. 2801-2809, 1999.

[6] R. Filosa, A. Peduto, S. D. Micco et al., "Molecular modelling studies, synthesis and biological activity of a series of novel bisnaphthalimides and their development as new DNA topoisomerase II inhibitors," Bioorganic \& Medicinal Chemistry, vol. 17, no. 1, pp. 13-24, 2008.

[7] V. Calvillo-Páez, R. R. Sotelo-Mundo, M. Leyva-Peralta et al., "Synthesis, spectroscopic, physicochemical and structural characterization of tetrandrine-based macrocycles functionalized with acridine and anthracene groups: DNA binding and anti-proliferative activity," Chemico-biological Interactions, vol. 286, pp. 34-44, 2018.

[8] C. Ying, S. Mao, X. Shi, K. Shen, and H. Wu, "Synthesis, crystal structure, DNA-binding properties and antioxidant activity of a copper (II) complex with naphthalimide schiff base," Zeitschrift Fur Anorganische Und Allgemeine Chemie, vol. 643, no. 18, pp. 1182-1190, 2017.

[9] J. Ladislav, K. U. Mária, S. Danica et al., "Cytotoxic 3,6-bis ((imidazolidinone)imino) acridines: synthesis, DNA binding and molecular modeling," Bioorganic \& Medicinal Chemistry, vol. 19, no. 5, pp. 1790-1801, 2011.

[10] M. K. Ibrahim, M. S. Taghour, A. M. Metwaly et al., "Design, synthesis, molecular modeling and anti-proliferative evaluation of novel quinoxaline derivatives as potential DNA intercalators and topoisomerase II inhibitors," European Journal of Medicinal Chemistry, vol. 155, pp. 117-134, 2018.

[11] I. H. Eissa, A. Metwaly, A. Belal et al., "Discovery and antiproliferative evaluation of new quinoxalines as potential DNA intercalators and topoisomerase II inhibitors," Archiv der Pharmazie, vol. 352, no. 11, Article ID e1900123, 2019. 
[12] I. H. Eissa, A. M. El-Naggar, and M. A. El-Hashash, "Design, synthesis, molecular modeling and biological evaluation of novel $1 \mathrm{H}$-pyrazolo [3,4-b] pyridine derivatives as potential anticancer agents," Bioorganic Chemistry, vol. 67, pp. 43-56, 2016.

[13] V. A. Bacherikov, J.-Y. Chang, Y.-W. Lin et al., "Synthesis and antitumor activity of 5-(9-acridinylamino) anisidine derivatives," Bioorganic \& Medicinal Chemistry, vol. 13, no. 23, pp. 6513-6520, 2005.

[14] S. Vispé, I. Vandenberghe, M. Robin et al., "Novel tetra-acridine derivatives as dual inhibitors of topoisomerase II and the human proteasome," Biochemical Pharmacology, vol. 73, no. 12, pp. 1863-1872, 2007.

[15] P. Belmont, J. Bosson, T. Godet, and M. Tiano, “Acridine and acridone derivatives, anticancer properties and synthetic methods: where are we now?" Anti-Cancer Agents in Medicinal Chemistry, vol. 7, no. 2, pp. 139-169, 2007.

[16] S. N. Tan, "The synthesis and study on optical characteristics of 1,8-naphthalimide derivative," Sun Yat-Sen University, Guangzhou, China, 2004, Master's thesis.

[17] R. Munawar, N. Mushtaq, S. Arif et al., "Synthesis of 9aminoacridine derivatives as anti-alzheimer agents," American Journal of Alzheimer's Disease \& Other Dementiasr, vol. 31, no. 3, pp. 263-269, 2016.

[18] G. F. Makhaeva, S. V. Lushchekina, N. P. Boltneva et al., "9substituted acridine derivatives as acetylcholinesterase and butyrylcholinesterase inhibitors possessing antioxidant activity for Alzheimer's disease treatment," Bioorganic \& Medicinal Chemistry, vol. 25, no. 21, pp. 5981-5994, 2017.

[19] L. N. Huo, "The synthesis and anti-tumor activities of acridine derivatives as DNA intercalator and the total synthesis study of nitidine chloride," Doctor's thesis, Guangxi Medical University, Nanning, China, 2014.

[20] Z. Chen, L. Wang, G. Zou, X. Cao, Y. Wu, and P. Hu, “A retrievable and highly selective fluorescent probe for monitoring dihydrogen phosphate ions based on a naphthalimide framework," Spectrochimica Acta Part A: Molecular and Biomolecular Spect roscopy, vol. 114, pp. 323-329, 2013.

[21] L. Du, "Synthesis, structure and properties of 1, 8-naphthanimide ligands and their complexes," M.S. thesis, Qingdao University of Science and Technology, Qingdao, China, 2009.

[22] J.-S. Lv, X.-M. Peng, B. Kishore, and C.-H. Zhou, "1,2,3Triazole-derived naphthalimides as a novel type of potential antimicrobial agents: synthesis, antimicrobial activity, interaction with calf thymus DNA and human serum albumin," Bioorganic \& Medicinal Chemistry Letters, vol. 24, no. 1, pp. 308-313, 2014.

[23] M. V. Berridge and A. S. Tan, "Characterization of the cellular reduction of 3-(4,5-dimethylthiazol-2-yl)-2,5-diphenyltetrazolium bromide (MTT): subcellular localization, substrate dependence, and involvement of mitochondrial electron transport in MTT reduction," Archives of Biochemistry and Biophysics, vol. 303, no. 2, pp. 474-482, 1993.

[24] W.-J. Cho, E.-K. Kim, I. Y. Park et al., "Molecular modeling of 3-arylisoquinoline antitumor agents active against A-549. a comparative molecular field analysis study," Bioorganic \& Medicinal Chemistry, vol. 10, no. 9, pp. 2953-2961, 2002.

[25] G. L. Ellman, K. D. Courtney, V. Andres, and R. M. Featherstone, "A new and rapid colorimetric determination of acetylcholinesterase activity," Biochemical Pharmacology, vol. 7, no. 2, pp. 88-95, 1961.

[26] R. Chen, L. Huo, Y. Jaiswal et al., "Synthesis and evaluation of anticancer activity of new 4-acyloxy derivatives of robustic acid," International Journal of Molecular Sciences, vol. 20, no. 21, p. 5336, 2019.

[27] L. J. Reed and H. Muench, "A simple method of estimating fifty per cent Endpoints12," American Journal of Epidemiology, vol. 27, no. 3, pp. 493-497, 1938.

[28] D. A. Koster, K. Palle, E. S. M. Bot, M.-A. Bjornsti, and N. H. Dekker, "Antitumour drugs impede DNA uncoiling by topoisomerase I," Nature, vol. 448, no. 7150, pp. 213-217, 2007.

[29] P. Yves, "DNA topoisomerase I inhibitors: chemistry, biology, and interfacial inhibition," Chemical Reviews, vol. 109, no. 7, pp. 2894-2902, 2009.

[30] Z. Yuan, S. Chen, C. Chen et al., "Design, synthesis and biological evaluation of 4-amidobenzimidazole acridine derivatives as dual PARP and topo inhibitors for cancer therapy," European Journal of Medicinal Chemistry, vol. 138, pp. 1135-1146, 2017.

[31] R. P. Rodrigues, S. P. Mantoani, J. R. D. Almeida et al., "Virtual screening strategies in drug design," Revista Virtual de Quimica, vol. 4, no. 6, pp. 739-776, 2012.

[32] K. E. Hevener, W. Zhao, D. M. Ball et al., "Validation of molecular docking programs for virtual screening against dihydropteroate synthase," Journal of Chemical Information and Modeling, vol. 49, no. 2, pp. 444-460, 2009.

[33] H. Tang, D. Zhao, and Z. Xue, "Exploring the interaction between Salvia miltiorrhiza and $\alpha$-glucosidase: insights from computational analysis and experimental studies," RSC Advances, vol. 8, no. 44, pp. 24701-24710, 2018.

[34] E. Scarpini, P. Schelterns, and H. Feldman, "Treatment of Alzheimer's disease; current status and new perspectives," The Lancet Neurology, vol. 2, no. 9, pp. 539-547, 2003.

[35] U. Holzgrabe, P. Kapková, V. Alptüzün, J. Scheiber, and E. Kugelmann, "Targeting acetylcholinesterase to treat neurodegeneration," Expert Opinion on Therapeutic Targets, vol. 11, no. 2, pp. 161-179, 2007. 